\title{
EKSISTENSI TUHAN DALAM PANDANGAN ATEISME
}

\section{Baharudin}

Fakultas Ushuluddin IAIN Raden Intan Lampung

Ateisme adalah suatu paham filsafat yang menolak adanya eksistensi Tuhan. Ateisme mempuyai bentuk yang bermacam-macam dan di kembangkan dalam aliran-aliran filsafat seperti Empirisme dengan tokohnya David Hume, aliran filsafat Positivisme dengan tokohnya Auguste Comte, aliran Materialisme dengan tokohnya Ludwig Feuerbach dan Karl Marx, aliran Humanisme dan Eksistensialisme dengan tokohnya Nietzsche dan J.P Sartre. Pada intinya mereka menolak dan menentang eksistensi Tuhan dan agama. Ia adalah musuh kemanusian, musuh agama dan kepercayaan terhadap Allah.

Kata Kunci: Eksistensi, Tuhan, Ateismeme. 
96 M. Baharudin

\section{A. Pendahuluan}

Dalam hati sanubari tiap-tiap manusia terkandung perasaan bahwa dibalik alam yang nyata ada suatu kekuatan yang berperan secara mutlak. Kekuatan itu bersifat pribadi yang berkehendak berkemauan. Pribadi itu di sebut Tuhan. ${ }^{1}$ Tuhan sama artinya tuan. Yaitu kata sapaan bagi orang yang di hormati, karena pangkat atau drazatnya di pandang lebih tinggi dari orang yang menyapa. Tuan di tujukan kepada sesama manusia, sedangkan Tuhan di tujukan kepada yang Maha Mulia dan Maha Kuasa.

Orang yang percaya pada agama-agama Samawi sepakat bahwa Tuhan, nama yang Maha Mulia, dari yang zat yang Maha suci yang di percayai dan manusia beramal, berusaha karenaNya. Dari pada-Nya-lah manusia hidup dan kepada-Nya manusia kembali. Amat suci lah Dia, dan kepada-Nya-lah terhimpun pujian dan pujaan. Tak terhitung banyak pujian yang harus di berikan kepada-Nya. Louis O. Kattisoff dalam bukunya Elements Of Philosophy menyebutkan bahwa Tuhan sebagai "Pencipta" ("Tuhan menciptakan langit dan bumi"), "Yang Tiada Berakhir", "Yang Abadi", "Yang Maha Kuasa”, Yang Maha Mengetahui”, dan barang kali juga "Yang Maha Ada”. Kemudian ada istilah-istilah seperti "Yang Adil”, "Yang Bijaksana”, "Yang Mengasihi”. ${ }^{2}$

Dalam sejarah manusia, terdapat beberapa keyakinan kepada Tuhan, ada yang berkeyakinan bahwa Tuhan itu ada (Theisme), ${ }^{3}$ ada pula yang berkeyakinan bahwa Tuhan itu tidak ada (Athaisme). Theisme dalam perkembanganya mempuyai banyak varian yaitu:

* Penulis adalah dosen prodi Aqidah dan Filsafat Fakultas Ushuluddin IAIN Raden Intan Lampung mengampu mata kuliah filsafat. SI di selesaikan di IAIN Raden Intan Lampung pada tahun 1988, S2 di Fakultas filsafat Universitas Gaja Mada Yogyakarta pada tahun 2001 dan S3 di selesaikan pada Fakultas filsafat Universitas Gaja Mada pada tahun 2009.

${ }^{1}$ N.A Rasyid Dt Mangkudun, Ketuhanan Yang Maha Esa Menurut Konsep Taubid, ( Jakarta, karya Indah, 1984) hlm. 11

2 Louis O. Kattsoff, Pengantar Filsafat. Di Terjemahkan dari Buku Elements Of Philosophy. Ahli Bahasa Soejono Soemargono, Yogyakarta, Tiara Wacana, 1987. Hlm. 448

3 Theisme adalah paham yang mengakui Tuhan sebagai ada yang personal dan transenden dan berpatrisipasi secara imanen dalam penciptaan dunia dari ketiadaan melalui aktus pencipta-Nya yang bebas. Arqom Kuswanjono, Ketuhanan dalam Telaah Filsafat Perenial Refleksi Pluralisme Agama di Indonesia, Yogyakarta, Filsafat UGM, hlm 29. Dalam faham Theisme alam ini tidak beredar menurut hukum-hukum dan peraturan-peraturan yang tak berubah, tetapi beredar menurut kehendak mutlak Tuhan. Oleh karena itu theisme mengakui adanya mu’jizat. Dalam theisme doa juga mempuyai tempat. Lihat Harun Nasution, Falsafat Agama, Bulan Bintang, Jakarta, 1979 , hlm. 43. 
Politeisme ${ }^{4}$ Dualisme, ${ }^{5}$ Oligateismeme, ${ }^{6}$ Henoteisme, ${ }^{7}$ Deisme, ${ }^{8}$ Panteisme, ${ }^{9}$ Panenteisme, ${ }^{10}$ dan Monoteisme. ${ }^{11}$ Menurut Hamersma Ateismeme mempuyai bentuk yang bervarian juga seperti : a. Anti-teisme, anti-teisme ini terdiri atas tiga paham: 1. Scienteisme, 2. Humanisme Ateismeme, 3. Materialisme dialektis, b. Ateismeme relegius dan Ateismeme yang mencari dialog dengan agama masehi. ${ }^{12}$ Dalam tulisan ini, penulis fokus telaahnya sekedar pada paham Ateismeme saja.

\section{B. Eksistensi Tuhan Dalam Pandangan Ateisme}

Sebagaimana dipaparkan dimuka bahwa orang yang percaya pada agama-agama Samawi sepakat bahwa Tuhan, nama yang Maha Mulia, dari yang zat yang Maha suci yang di percayai dan manusia beramal, berusaha karena-Nya. Dari pada-Nya-lah manusia hidup dan kepada-Nya manusia kembali. Amat suci lah Dia, dan kepada-Nya-lah terhimpun pujian dan pujaan. Tak terhitung banyak pujian yang harus di berikan kepada-Nya. Louis O. Kattisoff dalam bukunya Elements Of Philosophy menyebutkan bahwa Tuhan sebagai "Pencipta" ("Tuhan menciptakan langit dan bumi”), "Yang Tiada Berakhir", "Yang Abadi”, "Yang Maha Kuasa”, Yang Maha Mengetahui", dan barang kali juga "Yang Maha Ada". Kemudian ada istilah-istilah seperti "Yang Adil", "Yang Bijaksana", "Yang Mengasihi". Namun demikian dalam sejarah manusia

4 Politeisme, yaitu paham yang menyatakan adanya banyak Tuhan (dewa). Paham ini menganggap Tuhan ada dimana-mana termasuk dalam tempat-tempat yang dianggap keramt atau pada jimat-jimat. Setiap dewa mempuyai nama dan memainkan suatu peranan tertentu. Dewa-dewa tersebut diyakini keberadaanya serta dilakukan ritual pemujaan terhadap mereka. Arqom Kontowijoyo, Op Cit, hlm. 29

5 Faham ini hanya mengakui adanya dua dewa yaitu dewa baik dan dewa jahat. Dewa baik adalah dewa yang diyakini dapat memberikan kebaikan-baikan serta mengabulkan doa manusia, sedang dewa jahat adalah dewa yang dapat memberikan bencana dan kerusakan. Ibid

6 Oligataisme merupakan bagian dari politeisme akan tetapi paham ini mempercayai bahwa hanya beberapa dewa yang mempunyai fingsi dan kedudukan lebih tinggi dari pada yang yang lain. Beberapa dewa ini biasanya mendapat tempat istimewah dalam tempat masyarakat. Ibid.

7 Henoteisme adalah kepercayaan yang tidak menyangkal adanya Tuhan banyak, tetapi hanya mengakui satu Tuhan tunggal sebagai Tuhan yang disembah. Amsal Bakhtiar, Filsafat Agama: wisata-wisata Pemikiran dan Kepercayaan Manusia, Jakarta, Raja Grafindo Persada, hlm. 72

8 Deisme berasal dari kata Latin deus yang berarti Tuhan. Menurut paham ini Tuhan berada jauh dari luar alam (transcendent) yaitu tidak dalam alam (tidak immanen). Tuhan menciptakan alam, dan sesudah alam diciptakan-Nya, ia tak memperhatikan alam. Alam berjalan dengan peraturan-peraturan (sunnahtullah) yang tak berubah-ubah, peraturan-peraturan yang sesempurna-sesempurnanya. Dalam paham Deisme ini Tuhan dapat di umpamakan dengan tukang jam (the clockmaker) yang tidak capur tangan lagi dalam proses bergerakanya jam setelah jam itu dibuat. Arqom Kuntowijono, Op, Cit, hlm. 30

9 Pantaisme adalah suatu kepercayaan bahwa Tuhan berada dalam segala sesuatu, dan bahwa segala sesuatu adalah Tuhan. Titus Dkk, Persoalan-persoalan Filsafat, Jakarta, Bulan Bintan, tt, hlm. 44

10 Panenteisme berasal dari kata Pan-en-teisme (segala sesuatu ada di dalam Tuhan). Faham ini mengatakan bahwa dunia tidak dicampur adukan dengan Tuhan, namu tidak pula dipisahkan. Dunia merupakan ungkapan empiris Tuhan yang berada di dalam segala hal secara immanen dan sekaligus transenden. Kuntowijono, Op, Cit, hlm. 31

11 Monoteisme adalah suatu faham yang mengakui adanya hanya satu Tuhan. Lihat Louis O. Kattsoff, Pengantar Filsafat, Alih Bahasa Soejono Soemargono, Yogyakarta, 1987, hlm. 446 dan lihat Arqom Kuswanjono, Ketuhanan Dalam Telaah Filsafat Perennial: Refleksi Pluralisme Agama di Indonesia, Yogyakarta, Badan Penerbit Filsafat UGM, 2006. Hlm. 29-31

12 Harry Hamersma, Theologi Metafisik, Yogyakarta Seminari, 1978, hlm. 42 
terdapat suatu keyakinan yang tidak mengakui Tuhan itu ada. Paham tersebut di kenal orang dengan istilah Ateisme.

Ateismeme adalah suatu paham yang tidak mengakui Tuhan itu ada, atau yang mengakui Tuhan itu tidak ada. ${ }^{13}$ Arqom Kuswanjono menunjukan beberapa alasan orang mempuyai paham Ateisme:

a. Naturalisme, paham yang menganggap bahwa dunia empiris ini merupakan keseluruhan realita. Adanya alam tidak membutuhkan adanya bantuan dari luar. Semua kejadian di alam berada dalam siklus yang terus berjalan, sehingga tidak membutuhkan adanya kehadiran pihak lain untuk memahami alam, naturalisme bertentangan dengan supranaturalisme.

b. Kejahatan dan penderitaan. Jika Tuhan betul-betul Maha Kasih tentunya akan menghapus kejahatan. Apabila Ia Maha Kuasa pasti akan menghapus kejahatan ini. Kenyataannya kejahatan ini tetep ada, oleh karenanya Tuhan tidak dapat bersifat Maha Kuasa dan Maha Kasih.

c. Otonomi Manusia. Manakala Tuhan ada maka manusia secara otomatis tidak memberi kebebasan. Padahal kenyataannya manusia bebas. Jadi, Tuhan tidak ada.

d. Kepercayaan kepada Tuhan hanya merupakan hasil dari pikiran, harapan (wishful thinking) dan kebiasaan masayarakat. ${ }^{14}$

Sebagaimana dipaparkan di atas bahwa Ateismeme mempuyai bentuk yang bervarian:

a. Anti-teisme, paham yang melawan iman/kepercayaan secara aktif karena di anggap sebagai ancaman untuk manusia.

Menurut Hamersma bahwa anti-teisme terdiri atas tiga paham :

1) Scienteisme berpendapat bahwa semua peryataan yang tidak bisa di virifikasi adalah tidak bermakna. Karena semua kenyataan tentang Tuhan tidak dapat verifikasi, maka semua peryataan jenis ini tidak bermakna pula. Termaksud dalam hal ini adalah Positivisme logis dan Empirisme radikal.

2) Humanisma Ateismeme, menyangkal adanya Tuhan, karena pengesahan adanya Tuhan merintangi kebebasan manusia. Percaya akan Tuhan berarti mengasingkan manusia dari dirinya sendiri.

3) Materialisme dialektis, hekekat kenyataan adalah yang materil, sementara surga, kehidupan akhirat hayalah belaka. Menurut paham tersebut agama berbahaya karena merupakan cando yang akan membius dan melenakan manusia.

a. Ateismeme relegius, yaitu Ateismeme dalam teologi. Misalnya aliran ini yang menamakan sebagai radical theology yang mengumumkan Injil tanpa Tuhan, teologi kematian Allah.

b. Ateismeme yang mencari dialog dengan agama Masehi. Menurut aliran ini setiap agama pada dasarnya merupakan sebuah jalan buntu. Meskipun tidak mengakui adanya Tuhan, aliran ini tetap mengajak dialog agama Masehi. Dengan kata mereka dapat di katakan sebagai

13 Endang Saifuddin Anshari, Ilmu Flsafat \& Agama, Surabaya, Bina Ilmu, 1979, hlm. 111 14 Arqom Kuswanjono, Op Cit, hlm. 32-33 
Ateisme namun bukan anti-teis. ${ }^{15}$

\section{Tokoh-Tokoh Ateismeme Dalam Aliran-Aliran Filsafat}

1. Tokoh Ateismeme Dari Aliran Filsafat Positivisme ${ }^{16}$ (A. Comte)

a. Riwayat hidup

Auguste Comte lahir di Montpelier Prancis tahun 1798. ${ }^{17}$ Ia adalah figur yang paling representatif untuk positivisme sehingga dia di juluki sebagai bapak Positivisme. Dalam usia 25 tahun, dia studi di Ecole Polytechnique di Paris dan sesudah dua tahun di sana dia mempelajari pikiran-pikiran ideolog, tetapi juga Hume dan Condorcet. Saint-Simon menerimanya sebagai seketarisnya, dan sulit dipungkiri bahwa pemikiran Saint-Simon mempengaruhi perkembangan intelektualitas Comte. Mereka cocok dengan pandangan bahwa reorganisasi masyarakat bisa dilakukan dengan bantuan ilmu pengetahuan baru tentang perilaku manusia dan masyarakatnya. Pada tahun 1826, Comte sudah menemukan proyek filosofinya sendiri dan mulai mengajarkanya diluar pendidikan resmi. Untuk selanjutnya, dia juga tadak pernah menduduki jabatan resmi dikampus. Dia juga sempat sakit keras karena kerja keras, dan perkawinannya gagal. Bahka dia juga sempat mencoba bunuh diri, tapi gagal. Adikaryanya yang paling terkenal adalah Cours de Philosophie dalam 6 jilid. Dalam tulisan-tulisannya dia mengusahakan sebuah sintesis segala ilmu pengetahuan dengan semangat positifisme, tetapi usaha itu tidak rampung, sebab pada tahun 1857 dia meninggal dunia. ${ }^{18}$

b. Pengaruh A. Comte

Comte terutama penting sebagai pencipta ilmu sosiologi. Di Perancis ia juga penting untuk perkembangan ilmu lain. Pengaruhnya sebagai filosof paling besar di Inggris, dimana positivisme diterima dengan sangat baik oleh beberapa filosof dinegeri ini, juga dibeberapa negara lain positivisme Comte main peranan yang penting dalam pemikiran, seni, politik dan lain-lain.

c. Pikiran-pikiran pokok

Positivisme, asalnya adalah "positif", berarti yang di ketahui, yang faktual, dan yang fositif. Oleh karena itu, metafisika di tolak. Positivisme memandang agama sebagai gejala beradaban yang primitif. Auguste Comte tokoh Positivisme, membagi sejarah umat manusia atas tiga tahap.

15 Harry Hamersma, Op Cit, hlm. 42 dan lihat dalam Arqom Kuswanjono, Op, Cit, hlm 33-34

16 Istilah "positivisme" diperkenalkan oleh comte istilah itu berasal dari kata positiv. Budi Hardiman, $O p$, Cit, hlm. 204. Disini kata "positiv" sama artinya dengan faktual (apa yang berdasarkan fakta-fakta). Menurut positivisme, pengetahuan kita tidak pernah boleh melebihi fakta-fakta. Dalam hal ini, positivisme menegaskan bahwa pengetahuan hendaknya tidak melampoi fakta-fakta. Dalam penegasan itu lalu jelas yang ditolak positivisme, yakni metafisika. Penolakan metafisika disini bersifat definitif.

17 Titus dkk, Persoalan-persoalan filsafat, Jakarta, Bulan Bintang, 1974, hlm. 364.

18 Budi Hardiman, $O p$, Cit, hlm. 223-224 
Pertama, tahap Teologi, ${ }^{19}$ kedua tahap Metafisika, ${ }^{20}$ ketiga tahap positif. ${ }^{21}$ Bagi Comte bahwa tiga tahap perkembangan umat manusia tidak saja berlaku bagi suatu bangsa atau suku, tetapi juga individu dan ilmu. Ketika masih kanak-kanak, seseorang menjadi teolog. Ketika remaja dia menjadi metafisikus, dan ketika dewasa dia menjadi positif. Ilmu juga demikian, pada awalnya ilmu di kuasai oleh teologis, sesudah itu di abstraksikan oleh Metafisika dan akhirnya baru di cerahkan oleh hukum-hukum positif. ${ }^{22}$ Oleh karena itu paham positiv membatasi dunia pada hal-hal yang nyata, yang bisa di ukur dan yang bisa di buktikan kebenarannya. Karena agamamaksudnya Tuhan-tidak bisa di lihat, di ukur dan dibuktikan, maka agama tidak mempuyai arti dan faidah.

Menurut Amsal Bakhtiar, paham Positivisme mengatakan bahwa pada jaman dulu banyak pembicaraan yang tidak ada faidahnya dan tidak mengandung arti. Misalnya, "apa maksud Tuhan menciptakan alam?” pertayaan ini merupakan pertayaan yang kosong dan tidak berarti. Pertayaan demikian bukan saja karena kita tidak dapat mengetahui maksud Tuhan karena kita manusia, tetapi karena setiap susunan kata yang mengenai ke-Tuhanan tidak mengandung arti apapun.

Dari paparan di atas dapat di ketahui bahwa, dalam beberapa aspek, paham Positivisme terdapat hal-hal yang konstruktif untuk kehidupan umat manusia. Sebab, Positivisme menyuguhkan suatu metode ilmiah dan ukuran-ukuran yang dapat di pertanggung jawabkan secara empiris. Dalam hal ini, Positivisme menyumbangkan gagasan baru dalam kemajuan ilmu pengetahuan dan teknologi. Namun, dalam aspek lain positivisme mempersempit alam pada hal-hal yang terukur saja, tidak mau melihat alam yang lebih luas dan besar. Bahkan kesenangan

19 Dalam tahap ini, menurut comte, umat manusia mencari sebab-sebab terakhir dibelakang peristiwa alam dan menemukannya dalam kekuatan-kekuatan adi manusiawi. Kekuatan-kekuatan ini, entah disebut dewa-dewa atau Allah, dibayangkan memiliki kehendak atau rasio yang melampui manusia. Zaman ini lalu dibagi menjadi tiga sub-bagian. Pada sub-tahap yang paling premitif dan kekanak-kanakan, yaitu tahap fetisisme atau animisme, manusia menganggap objek-objek fisik itu berjiwa, berkehendak berhasyrat. Pada tahap berikutnya, politeisme, kekuatan-kekuatan alam itu diproyeksikan dalam rupa dewa-dewa. Akhirnya, tahap monoteisme, dewa-dewa dipadukan menjadi satu kekuatan adi manusiawi yang disebut Allah, lihat Budi Hardiman, Filsafat Modern dari Machiaveli sampai Nietzsche, Jakarta, Gramedia Pustaka Utama, 2004, hlm. 206

20 Metafis.ika berasal dari istilah Yunani: ta meta ta physika: artinya "sesuatu atau dibelakang realitas fisik. Istilah metafisika biasanya dihubungkan dengan nama Ariestoteles karena dua pertimbangan. Pertama, secara pribadi sebenarnya Ariestoteles tidak pernah memakai istilah metafisika: Ariestoteles sendiri menyebutnya; "filsafat pertama” (The First Philosophy). M. Baharuddin, mengenal Metafisika, Bandar Lampung, Fakultas Ushuludin IAIN Raden Intan Lampung, 2007, hlm. 1 Dalam tahap metafisika ini, umat manusia berkembang dalam pengetahuannya seperti seorang melangkah pada masa remajanya. Kekuatan adimanusiawi dalam tahap sebelumnya itu sekarang diubah menjadi abstraksi-abstraksi metafisis, Ibid. Dan lihat Harry Hamersma, Tokoh-tokoh Filsafat Barat Modern, Jakarta Gramedia, 1986, hlm. 55.

21 Menurut Comte dalam tahap positvisme ini akhirnya, umat manusia mencapai kedewasaan mentalnya dalam tahap positif. Pada zaman ini umat manusia tidak lagi menjelaskan sebab-sebab diluar fakta-fakta yang teramati. Pikiran hanya memusadkan diri pada yang faktual yang sebenarnya bekerja menurut hukum-hukum umum, misalnya hukum grafitasi. Baru pada tahap inilah ilmu pengetahhuan berkembang penuh. Ilmu pengetahuan tidak hanya melukiskan yang real, tetapi juga bersifat pasti dan berguna. Budi Hardiman, Op, Cit, hlm.207

22 Lihat Charles Hartshorne dan Wiliam L. Reese, Philophers Speak Of God, Chicago: The University Ff Chicago Press, 1953, hlm. 110 baik juga baca pada Amsal Bakhtiar, Filsafat Agama: Wisata Pemikiran dan Kepercayaan Manusia, Jakarta, Raja Grafindo Persada, 2009, hlm. 116 
rohani atau penderitaan rohani di anggap sebagai sesuatu yang tidak berarti. Padahal kesenagan dan penderitaan, kendati tidak dapat di ukur dengan tepat, di alami oleh semua orang hingga penganut Positivisme sendiri.

Paham Positivisme terlalu mengetapikan kemapuan akal pada hal-hal yang dapat di uji secara empiris. Padahal akal tidak hanya tergantung pada pengujian secara empiris. Akal mampu merekeyasa sesuatu yang belum pernah di lihatnya dan akal juga mampu menulis 'tanpa memakai kertas dan pulpen'. Tulisan itu dapat digambarkan dalam pemikiran saja tanpa di empiriskan. Karena, Positivisme sebenarnya harus mengakui hal yang demikian sebagai suatu realitas. Dengan demikian, kepercayaan kebetulan berarti tidak mustahil karena daya akal mampu mencapai realitas di balik dunia empiris. ${ }^{23}$

2. Tokoh Paham Ateismeme Dari Filsafat Empirisme ${ }^{24}$ ( Davit Hume)

a. Riwayat Hidup

David Hume, yang paling di kenal dari kaum Empirisme, lahir dekat di Edinburgh, Scotland, tahun 1711. Ia belajar hukum dan sastra filsafat. Dan pernah bekerja sebagai diplomat di Inggris, Prancis, Austria dan Italia. Diperancis, Hume tinggal beberapa tahun di La Flche, tempat dimana Discartes telah bersekolah. Di Paris dia bertemu dengan Jean-Jacques Rouseau.. Hume meninggal di Edinburgh tahun 1776. ${ }^{25}$

b. Pengaruh Davit Hume

Walaupun Hume skeptikus, filsafatnya cukup berpengaruh. Kata Kant: "oleh Hume saya di bangunkan dari tidur dogmatis". Pada Hume empirisme berhenti, walaupun banyak unsur empirisme masih akan diteruskan dalam fajar budi di Perancis.

c. Pikiran-pikiran pokok

Dalam bidang agama dan etika menurut Harry Hamersma pikiran Hume cukup Skeptisistis. Bagi Hume, secara teoritis tidak dibuktikan apa-apa dari perkataan-perkataan tentang agama dan etika. Kepentingan agama dan etika hanya dapat di buktikan secara praktis. Hume tidak menghargai agama terlalu tinggi. Dia membedakan dua bentuk agama yaitu "natural relegion", yang berasal dari akal budi, dan "agama rakyat", yang penuh fanatisme. "natural relegion", mempuyai harga, tetapi "agama rakyat" itu hanya berbahaya. ${ }^{26}$

Pandangan David Hume tentang eksistensi Tuhan dia mengatakan ketika kita percaya kepada Tuhan sebagai pengatur alam ini, kita beradapan dengan delima. Kita berfikir tentang Tuhan menurut pengalaman masing-masing, sedangkan itu hanya setumpuk persepsi dan

23 Amsal Bakhtiar, Op, Cit, hlm. 118

24 Empirisme. Istilah ini berasal dari kata Yunani emperia yang berarti “pengalaman”. Empirisme memilih pengalaman sebagai sumber utama pengenalan dan yang dimaksudkanya ialah baik pengalaman lahiriah yang menyangkut dunia maupun pengalaman batinniah yang menyangkut pribadi manusia saja..., empirisme berpendapat bahwa pengetahuan berasal dari pengalaman, sehingga pengenalan inderawi merupakan bentuk pengenalan yang paling jelas dan sempurna. Lihat K. Bertens, Ringkasan Sejarah Filsafat, Yogyakarta, Kanesius, 1981, 50. Aliran empirisme memuncak pada Davit Hume, sebab dia menggunakan prinsip-prinsip empiristis dengan cara yang paling radikal. Ibid. 52 .

25 Harry Hamersma, Tokoh-tokoh Filsafat Barat Modern, Jakarta, Gramedia, 1986, hlm. 22

26 Ibid. 
koleksi emosi saja. Seterusnya, bagaimana kita dapat mengatakan Tuhan itu Maha Sempurna dan Maha Kuasa sedangkan di alam terjadi kejahatan dan berbagai bencana. Lihat umpamanya kelaparan, gunung meletus, dan angin topan. Seyogyanya, alam ini juga sempurna sesuai dengan penciptanya, tetapi teryata tidak, Tuhan juga sumber kejahatan, terbatas, dan memiliki sifat mencintai dan membenci. Penelitian tentang dunia, demikian Hume, tidak mampu membuktikan Tuhan kecuali Tuhan itu tidak sempurna, seperti dunia. Selanjutnya Hume menyatakan bahwa kita tidak tau menau tentang alam lain, kita hanya tau alam yang kita diami ini. Karena itu, alam lain tidak jelas, dan pengetahuan kita terbatas mengenainya. ${ }^{27}$ Selanjutnya Hume menyatakan, tidak ada bukti yang dapat di pakai untuk membuktikan bahwa Tuhan ada dan bahwa Ia penyelenggara dunia. Juga tidak ada bukti bahwa jiwa tidak dapat mati. Dalam praktik orang-orang yang beragama selalu mengikuti 'kepercayaan', yang di anggap pasti, sedangkan akal tidak bisa membuktikannya. Menurut Hume, banyak sekali keyakinan agama yang merupakan hasil hayalan, tidak berlaku umum dan tidak berguna baik hidup. Agama, menurut Hume, bukan disebabkan karena penyelewengan dari wahyu yang asli, yaitu dari monoteisme ke politeisme dan bukan juga dari politeisme ke monoteisme. Akan tetapi, agama berasal dari penghargaan dan ketakutan manusia terhadap tujuan hidupnya. Itulah yang menyebabkan manusia mengangakat berbagai dewa untuk di sembah. ${ }^{28}$

Mu'jizat adalah ajaran agama yang juga diserang oleh David Hume. Dia memberikan lima alasan untuk menolak mu'jizat. Pertama, sepanjang sejarah mu'jizat tidak pernah diakui oleh sejumlah ilmuan dan kaum terpelajar. Kedua, sebagaian manusia memang mempuyai kecenderungan untuk percaya kepada peristiwa-peristiwa yang luar biasa, namu keyakinan ini tak mendukung kebenaran mu'jizat. Ketiga, kajian peradaban membuktikan bahwa mu'jizat hanya cocok terutama bagi masyarakat terbelakang, sedangkan bagi masyarakat yang telah maju justru menolaknya. Keempat, semua agama wahyu memonopoli kebenaran mu'jizat. Kelima, data sejarah yang dapat dipercaya menunjukan bahwa peristiwa-peristiwa di dunia ini jelas. ${ }^{29}$

Dari paparan di atas dapat diketahui bahwa, Hume mengabaikan peran akal dalam menangkap realitas. Padahal akal mampu menggabungkan peristiwa-peristiwa yang lampau dengan peristiwa yang sekarang dan bahkan mengistimasikan sesuatu untuk yang akan datang. Akal juga mampu memberikan ide-ide umum tentang fakta-fakta yang beragam. Adapun fakta atau data hanya sebagai alat untuk menyimpulkan saja, tetapi bukan faktor utama. Daya akal yang semakin kuat tidak membutuhkan fakta dan data lagi. Akal yang demikian mampu mencapai wujud yang tidak bermateri, yaitu Tuhan. Jadi, Tuhan secara a priori mampu di jelaskan oleh kekuatan akal. Dengan demikian, kesimpulan Hume tentang daya dan kemampuan akal terkesan sangat dangkal dan terburu-buru. ${ }^{30}$ Selain itu Hume terlalu mengetapikan semua realitas dalam kajian empiris, sehingga dia terjerumus pada determinisme empiris. Realitas alam

27 Amsal Bakhtiar, Omp, Cit, hlm 110

28 Ibid. Baik lihat Davit Hume, An Enguiry concerning Human Uanderstanding, (Chicago: Chicago University, 1952, hlm. 470 dan lihat Amsal Bakhtiar, Op, Cit, hlm. 111.

29 Ibid.

30 Amsal Bakhtiar, Op, Cit, hlm. 113 
menjadi sempit, serta mutlak dan tidak pernah berubah. Padahal realitas sangat luas dan di luar alam empiris masih terdapat wujud lain.

Sekeptisisme Hume terhadap agama juga bedasarkan atas determinisme yang kaku ini. Alam empiris terwujud dari dua hal yng saling bergantian yaitu kebaikan dan kejahatan. Kalau Tuhan Maha Baik, demikian Hume, kenapa Tuhan tidak menghilangkan kejahatan? Untuk problem ini dapat dijawab bahwa kejahatan adalah bagian dari dunia yang tidak sempurna. Kekuasaan Tuhan tidak di ukur lewat entitas yang tidak memiliki kekutan sama sekali atau lewat kekuatan yang kurang. Tuhan memang berkuasa, manusia juga berkuasa. Tuhan Maha bebas, dan manusia juga bebas. Tetapi kebebasan dan kekuasaan manusia lebih rendah tingkatannya ketimbang kebebasan dan kekuatan Tuhan. Dan dengan demikian, dalam hal ini kesempurnaan kebebasan Tuhan diukur lewat kekurangan kebebasan manusia. ${ }^{31}$

3. Tokoh Paham Ateismeme Dari Filsafat Materialisme ${ }^{32}$ (Ludwig Andreas Feuerbach dan Karl Marx)

\section{Ludwig Andreas Feuerbach}

a. Riwayat Hidup

Ludwig Andreas Feuerbach lahir di Landshut Jerman, tahun 1804 ia belajar teologi di Heidelberg dan filsafat di Berlin pada Hegel. Feuerbach termasud di antara murid-murid Hagel dari "sayap kiri". Feuerbach menerima metode dialektis tetapi menolak isi ajarannya. Feuerbach pernah mengajar di universitas, tetapi ia bekerja terutama sebagai pengarang. Ia meninggal tahun $1872 .{ }^{33}$

b. Pengaruh Ludwig Andreas Feuerbach

Feuerbach mengubah idialisme Hegel menjadi materialisme. Dengan demikian ia telah mempersiapkan jalan dengan demikian ia mempersiapkan jalan untuk pemikir-pemikir seperti Marx, untuk materialisme dialektis.

Dengan nama ejekan Feuerbach kadang-kadang disebut "bapak gereja dari ateisme". karena teorinya tentang proyeksi dan aliansi telah menjadi "tradisi" dalam ajara kebayakan ateis setelah Feuerbach.

31 Ibid.

32 Materialisme adalah suatu istilah yang sempit dan merupakan bentuk naturalisme yang lebih terbatas; materialisme pada umumnya mengatakan bahwa dunia ini tak ada selain materi, atau bahwa natur (alam) dan dunia fisik adalah satu. Istilah materialisme dapat diberi definisi dengan beberapa cara diantaranya pertama: materialisme adalah teori yang mengatakan bahwa atom materi yang berada sendiri dn bergerak merupakan unsurunsur yang membentuk alam dan bahwa akal dan kesadaran (consciusness) termaksuk didalamnya segala proses psikikal merupakan metode materi tersebut dan dapat disederhanakan menjadi unsur-unsur fisik; kedua definisi tersebut mempuyai implikasi yang sama, walaupun condom untuk menyajika bentuk materialisme yang lebih rasional. Materialisme modern mengatakan bahwa alam itu merupakan kesatuan material yang tak terbatas; alam, termaksud didalamnya segala materi dan energi (gerak atau tenaga selalu ada dan akan tetap ada, dan bahwa alam adalah realitas yang keras, dapat disentuh, material, objektif, yang dapat diketahui oleh manusia. Materialisme modern mengatakan bahwa materi ada sebelum jiwa, dan dunia material adalah yang pertama sedangkan pemikiran tentang dunia adalah nomor dua. Lihat Charles S. Seely, Modern Materialism: Philosophy of Action (New York: Philosophical Liberary, 1990, hlm 7).

33 Harry Hamersma, Op, Cit, hlm. 63-64 
c. Pikiran-pikiran pokok

1) Tuhan sebagai proyeksi dan Agama sebagai aliansi

Teori proyeksi mengatakan bahwa hakekat Tuhan tak lain dari pada hakekat manusia yang di absolutkan dan di objektifkan sama dengan mengatakan bahwa Tuhan adalah hasil "proyeksi diri manusia sendiri" dengan proyeksi diri sendiri yang di maksudkan bahwa manusia memiliki kekuatan-kekuatan hakiki. Kekuatan hakiki manusia itu terbatas dan tidak sempurna, maka dia membayangkan adanya sebuah kenyataan yang memiliki semua itu secara tak terbatas. Kenyataan itu lalu di bayangkan berada di luar dirinya, sebuah kenyataan objektif. Kenyataan itu sebenarnya tidak lain daripada objetifikasi kesadaran diri manusia sendiri, dan dalam bahasa Feuerbach disebut proyeksi diri. ${ }^{34}$

Kaitannya dengan teori aliansi, dia berpendapat bahwa proyeksi diri itu adalah sebuah aliansi diri. Menurut Feuerbach dengan memproyeksikan dirinya ke luar, manusia lalu menganggap hasil preyeksinya itu sebuah sesuatu yang lain darinya sendiri. Hasil proyeksinya itu mengahadapi dirinya sebagai objek. Manusia lalu meletakan dirinya lebih hina daripada hasil proyeksinya sendiri, misalnya: manusia itu lemah, sedangkan Tuhan Maha Kuasa, manusia itu jahat, sedang Tuhan itu suci, dst. Dengan semua proses ini, manusia malah terasing dari dirinya sendiri, sebab ia tidak lagi mengenali bahwa Tuhan yang di agungkannya itu tak lain dari hakekatnya sendiri. ${ }^{35}$

Kalau Tuhan adalah aliansi diri manusia dari dirinya sendiri, agama tentu adalah sebuah kenyataan yang negatif yang harus di atasi oleh manusia sendiri. Manusia mengaliansikan dirinya dalam agama. Akan tetapi, Feuerbach tidak langsung mengatakan bahwa agama itu siasia. Proyeksi diri itu memang mengaliansikan manusia dari dirinya, tetapi manusia tidak dapat menghindarinya, sebab proyeksi diri itu adalah hakekat kesadaran dirinya akan hakekatnya sendiri. Baru sesudah manusia sadar akan hakekatnya secara penuh, dia bisa mengatasi keterasingkannya. Menurut Feuerbach, dalam agama kristen proyeksi diri itu mencapai puncaknya. Manusia misalnya, idealisasikan menjadi putra Allah. Puncak itu bagi Feuerbach justru harus dicapai lebih dahulu sebelum kita meninggalkannya menuju sebuah antropologi. Dengan pergantian itu, manusia akan bangun dari mimpi-mimpinya dan mulai menyadari bahwa dia adalah tujuan bagi dirinya sendiri.

2) Tuhan itu hakekat manusia

Menurut Feuerbach agama mengajar betapa agung manusia. Semua mimpi manusia diberi bentuk dan nama dalam Tuhan. Itu berarti bahwa agama mengajar kita tentang hakekat manusia "saya merendahkan Teologi menjadi Antropologi", kata Feuerbach, "tetapi dengan demikian saya menaikan Antropologi menjadi Teologi”. Teologi itu Antropologi. Artinya: dalam objek agama, yang disebut teos “Tuhan”, hanya di ungkapkan hekakat manusia. Tuhan itu bukan asal manusia, manusia itu justru asal Tuhan.

34 Budi Hardiman, Filsafat Modern: dari Machiveli sampai Nietzsche, Jakarta, Gramedia, Pustaka Utama, 2004, hlm. 230

35 Ibid. 
Menurut Feuerbach Tuhan adalah mimpi yang paling bagus dari hati manusia dan manusia merasa paling bebas, paling diberkati di dalam agamannya. Dalam agama manusia "merayakan hari minggunya". Tuhan adalah keluhan yang terungkapkan dari paling dalam hati manusia. Tuhan adalah pusat perasaan. Oleh karena itu Tuhan telah menjadi manusia dan Tuhan telah bangkit dari kematian. ${ }^{36}$

Feuerbach juga memandang: kehidupan hari akhir tidak lain hanyalah kehidupan manusia ini, dengan meganggap bahwa Tuhan itu tidak lain manusia jika ia bijaksana, adil dan wajib. Sedangkan jarak-yang diajarkan oleh berbagai agama-agar kehidupan manusia dan kehidupan akhirat harus dilenyapkan, agar manusia menyatu jiwa dan kalbunya, baik di dunianya yang sekarang maupun dimasa yang akan datang. Melalui pemusatan seperti ini di alam nyata, maka akan timbul kehidupan baru bagi manusia, muncul karya-karya dan pemikiran besar, serta pemimpin kali berbesar dari umat manusia.

Jadi, keimanan dan keyakinan kita terhadap kehidupan akhirat yang lebih tinggi adalah tak berguna. Dan jika kita ingin menciptakan kehidupan itu, maka kita ciptakan tapi, untuk keinginan itu, kita harus menggantikan rasa cinta kepada Tuhan dengan cinta kepada manusiasebagai agama satu-satunya yang paling benar. Keimanan kepada Tuhan harus kita ganti dengan keimanan kepada manusia, kemapuan dan kebesarannya. Kita yakini bahwa tujuan akhir manusia bukanlah datang dari luar atau zat yang lebih tinggi, tetapi dari manusia itu sendiri. ${ }^{37}$

\section{Karl Marx}

\section{a. Riwayat Hidup}

Karl Marx adalah keturunan Yahudi. Ayahnya seorang pengacara. Dengan usia 6 tahun dia di baktis masuk agama Kristen Protestan. Setelah menyelesaikan pendidikan dasarnya dikota kelahirannya, dia masuk universitas Bonn, lalu pindah ke universitas Berlin. Pada awalnya dia tertarik pada ilmu hukum, tetapi kemudian meminati filsafat, khususnya Hagel. Marx bukanlah mahasiswa teladan di Berlin, ayahnya pernah menegurnya dengan keras karena ia hidup amburadul dan hilir mudi ke-berbagai pengetahuan tanpa jelas arahnya. ${ }^{38}$ Ketika di Berlin, Marx bergambung kelompok yang disebut Dokterclob, yang tak lain adalah salah satu kelompok Hegelian muda. Disini ia tidak berlangsung lama, karena lama-kelamaan dia tidak merasa puas dengan kelompok ini. Marx melanjutkan setudi di universitas Jena dan meraih gelar Dokternya disana pada usia 23 tahun. Tidak lama kemudia dia pindah ke Paris dan menjadi editor Deutchfranzosiche jahrbucher. Oleh keterlibatan praktisnya terhadap masalah-masalah ketimpangan sosial itu pemikiran Marx diradikalkan dan kerap meyerang pemerintah Jerman. Akibatnya, dia di usir dari Paris dan pindah ke Brusel. Di kota ini, bersama Engels dia menerbitkan manifest der Kommunisttisechen Partei. Marx melalui revolusi 1848 dengan semangat radikal sampai pada akhir revolusi itu dia ditahan oleh pihak yang berwenang dan di adili sebagai

36 Harry Hamersma, Op, Cit. Hlm. 65-66

37 Muhammad Al Bahiy, Pemikiran Islam Modern, Judul Asli "Al fikrul Islam Al Hadist Wa Shiratuhu bil Istimaril Garbiyyi” Jakarta, Pustaka Panjimas, 1986, hlm. 209-210

38 Budi Hardiman, $O p$, Cit, hlm. 232 
orang yang membahayakan negara. Dia di usir dari negaranya dan menetap di Inggris. Disini Marx menghabiskan sebagian besar waktunya untuk menulis, sementara kondisi keuangannya memburuk dan keluarganya terlantar. Marx memiliki tuju anak. Empat di antaranya mati karena kecelakaan. ${ }^{39}$

\section{b. Pengaruh Karl Marx}

Betapa besar pengaruh Karl Marx dalam abad ini. Banyak sekali orang hidup dibawah suatu ideologi yang seluruhnya atau separuh marxistis, di Eropa, Asia, Afrika, dan lain sebagainya. Dan semua itu merupakan hasil suatu perkembagan yang sangat cepat, karena meskipun ideologi Marx baru mulai main peranan yang penting sejak revolusi oktober 1917 di Rusia, namu 60 tahun kemudian sepertiga penduduk dunia sudah hidup dalam suatu negara komunistis, dan ratusan juta orang lain hidup dalam suatu negara yang sosialis. ${ }^{40}$

c. Pikiran-pikiran pokok

Marx telah belajar dari Feuerbech bahwa agama merupakan aliansi bedasarkan proyeksi. Hakekat manusia di beri bantu dan nama "Tuhan". Tetapi dengan menciptakan "Tuhan" ini manusia di asingkan dari dunia kini dan di sini. Kalau hakekat manusia di letakan diluar dirinya sendiri, manusia kehilangan sesuatu yang sangat penting. Maka proses ini harus di balikan lagi, supaya manusia di kembalikan pada dirinya sendiri. ${ }^{41}$ Menurut Harry Hamersma Marx melengkapi teori Feuerbach. Feuerbach hanya memperhatikan "bagaimana manusia menciptakan Tuhan dan surga". Marx menerangkan "mengapa-nya". Manusia melarikan diri dalam suatu mimpi agama, sebab penderitaannya dari struktur-struktur sosial-ekonomi mengatasi kekuatannya.

Manusia membutuhkan obat bius, candu, dan menemukan itu dalam agama. Tetapi itu bukan terapi. Manusia hanya dapat sembuh kalau dia mengatasi aliansi sosial-ekonomi yang merupakan sebab aliansi relegius. ${ }^{42}$ Selanjutnya Marx menyatakan, agama adalah candu karena ia berada pada posisi yang bertolak belakang dengan pandangannya. Menurut Muhammad Al Bahiy, kaum marsis secara khusus menyatakan bahwa ajaran Kristen ortodoks adalah "kekuasaan" yang menghambat perumbahan atau "kemajuan" dunia, sebab gereja ini memiliki kekuasaan politik dan sepiritual yang di pakai untuk memperkuat posisinya yang lalu setelah Revolusi Merah melawan kekaisaran. Gereja ini menghendaki kemuduran dan menolak kemajuan yang memang di kehendaki oleh suatu perubahan.

Di samping hal-hal di atas Karl Marx juga menyatakan, agama bagi kelas elit di jadikan alat legitimasi untuk mempetahankan ketidakadilan dan menamakan 'moralitas' sesuai dengan kepentingan mereka. Di sisi lain agama bagi kaum buruh di anggap pelarian dari penindasan. Menurut Marx agama adalah bagian dari kelas buruh yang menderita. Mereka tidak mampu melawan struktur kelas yang begitu kuat, sehingga mereka mencari kekuatan 'supernatural' untuk menolong mereka. Dari sini muncul lah Tuhan-Tuhan yang sesuai dengan kebutuhan

39 Ibid.

40 Harry Hamersma, Op, Cit, hlm. 74

41 Ibid 68

42 Ibid. Hlm, 70 
mereka. Orang miskin Tuhannya adalah yang kaya. Orang yang tertindas, Tuhannya adalah yang kuat, dan orang-orang yang berperang Tuhan mereka adalah yang kemenangan. Menurutnya jika sosialisme muncul, tidak seorangpun yang kelaparan, dan tidak seorangpun akan tertindas. Karena itu, agama akan mati dengan sendirinya sebagaimana halnya dengan Negara. ${ }^{43}$

Karl Marx sendiri mengakui bahwa dia penganut Ateismeme yang paling radikal. Dia mengkritik Cassendi yang ingin mempersatukan filsafat atei Epicurus dengan agama Kristen. Marx berkata. "hal ini seolah-olah seperti melemparkan jubah seorang biarawati Kristen ke atas tubuh seorang jenius Yunani yang indah dan elok". ${ }^{44}$ Bahkan sebelum menemukan bakatnya sebagai pembaharu sosial atas nama filsafat, Marx yang msih muda pernah mengatakan, "saya membenci segala macam Tuhan", pada saat itu, satu-satunya "ketuhanan yang siap dibelanya adalah pikiran". ${ }^{45}$

Kritik Feuerbach dan Mark terhadap agama tidak dalam. Ini terbukti kritik Mark tidak diperkaya dengan dogma agama yang sangat fundamental tentang prinsip-prinsip sosial dalam agama Kristen. Sebenarnya, kalau mau meneliti lebih dalam lagi, Mark tentu akan menemukan sikap orang-orang Kristen yang sejalan dengan sosialisme dan anti penindasan rakyat kecil. Begitu juga kalau tidak terpaku pada realitas sosial keagamaan di Barat saja, tentu dia akan mendapatkan wawasan yang luas tentang agama dan masyarakatnya.

Karena itu, Ignace Lepp, seorang yang pernah menjadi Ateisme selama 27 tahun, berkomentar, "Ateismeme Marx tidak ilmiah" dan kalau dilihat dari latar belakang Mark, tanpa emosinya yang tidak stabil. ${ }^{46}$ Sedangkan menurut Muhammad Al Bahiy, Marx dengan ajarannya yang dikenal dengan Marxisme adalah musuh kemanusiaan. Musuh agama dan kepercayaan terhadap Allah. Musuh hak milik pribadi. Musuh kebebasan berfikir, berpendapat, bekerja, memilih sistem hidup dan pembinaan rumah tangga! ${ }^{17}$

Selain hal di atas, Muhammad Al Bahiy menyatakan "sesungguhnya filsafat marsisme yang diajarkan Karl Marx selain mengandung berbagai kontradiksi-merupakan suatu propaganda bagi kemunduran kemanusian dan umat manusia. Ia mengajakan kepada kebudakan "pemaksaan", "paganisme", moral dan nilai-nilai "kebinatangan". ${ }^{8}$ "Perut" adalah tujuan dan sekaligus sebagai sarana dari kehidupan manusia. Tujuan manusia hidup ialah bekerja agar ia bisa makan. Cara menundukan manusia yakni dengan tidak memberinya makan, sehingga terdapat suatu kesimpulan "bekerja dan hasil”, bekerja untuk makan, bukan untuk hidup.

43 Harsja W. Bachtiar (ed), percakapan dengan Sidney Hook tentan 4 Masalah Filsafat, Jakarta, Jambatan, 1980, hlm. 129

44 Amsal Bakhtiar, Op, Cit, hlm. 124

45 Ibid, hlm 124-125

46 Ibid. 127.

47 Muhammad Al Bahiy, Op, Cit, hlm. 251

$48 \mathrm{Ibid}$, hlm. 227-228 
4. Tokoh Paham Ateismeme Dari Filsafat aliran Humanisme ${ }^{49}$ dan Eksistensialisme ${ }^{50}$ dengan tokohnya (Nietzsche dan J.P Sartre)

\section{Nietzsche}

a. Riwayat hidup

Friedrich Nietzsche lahir di Rocken di Jerman Timur, 1844. Ayahnya seorang pendeta Lutheran, kakenya guru besar teologi ${ }^{51}$ Nietzsche termasuk filosof Ateisme yang paling ektrem dalam jaman modern, terutama pikirannya tentang Tuhan dan agama, kritiknya agama Kristen di kemukakan tersebar dalam berbagai buku. Kritiknya itu mencapai puncaknya ia tulis dalam bukunya anti Kristus yang sudah selesai ditulis pada tahun 1888, tetapi baru diterbitkan pada tahun 1995.

Tahun 1869, waktu Nietzsche berumur 25 tahun, ia menjadi guru besar di Basel, Swis. Kuliahnya sangat arsenal, tetapi ia sama sekali tidak disenangi oleh Profesor lain. Tahun 1879 ia sudah dipensiunkan. Karena kesehatannya tidak beres. Dengan demikian mulai hidupnya sebagai "gelandangan intelektual". Nietzsche berjalan terus menerus keliling Swis, Prancis, dan Italia; dan hanya hidup dikamar-kamar hotel. Dalam periode ini diterbitkan kepabanyakan bukunya. Tahun 1889 ia menjadi sakit jiwa di Turin, Italia. Selama 10 tahun ia dirawat oleh ibunya dan kakaknya. Tahun 1900 ia meninggal, terkennal sebagai "filosof dengan palu" dan "Nabi kematian Allah". 52

b. Pengaruh Nietzsche

Tulisan-tulisan Nietzsche diterbitkan dalam banyak bahasa, dalam oplah yang besar, sampai sekarang. Tulisannya juga muda sekali dibaca. Filsafat Nietzsche mewakili suatu gaya hidup yang diberi nama macam-macam nama:individualisme, vitalisme, dan eksitensialisme.

c. Pikiran-pikiran pokok

Sebagaimana tokoh-tokoh Ateisme yang lain, Nietzsche sebagai tokoh Ateisme juga menolak adanya eksistensi Tuhan. Nietzsche tidak sekedar menolak eksistensi Tuhan tetapi juga meyerang Tuhan. Dengan matinya Tuhan, menurut Nietzsche manusia baru bisa bebas berbuat dan bertindak. Sebab selama ini manusia dikungkung oleh nilai-nilai agama, seperti pahala dan dosa. Sekarang Tuhan sudah mati dan terkubur, oleh karena itu manusia tidak usah takut lagi

49 Humanisme, istilah humanisme berasal dari humanitas, yang berarti pendidikan manusia dengan bahasa Yunani disebut paideia. Humanisme menegaskan bahwa manusia adalah ukuran segala sesuatu. Kebebasan manusia adalah salah satu tema pokok humanisme. Pico salah seorang tokoh Humanisme berkata, "manusia dianugrahi kebebasan memilih oleh Tuhan dan menjadikannya pusat perhatian dunia. Dengan posisi itu manusia bebas memandang dan memilih yang terbaik. Nicola Abbagnano, Humanisme, Dalam The Encyclopedia of Philosophy, vol, 3, New York, Nacmilan Publishers, 1967, hlm. 70 dan lihat Amsal Bakhatiar, Op, Cit, hlm. 146.

50 Eksistensialisme tidak mudah membuat definisi eksistensialisme. Kesulitannya kerena kalau eksistensialis sendiri tidak sepakat mengenai rumusan tentang apa sebenarnya eksistensialis itu. Ahmad Tafsir, Filsafat Umum: Akal dan Hati sejak Thales sampek James, Bandung, Remaja Rosda Karya, 1990, hlm1991. Sekalipun demikian, ada sesuatu yang disepakati: baik filsafat eksistensi maupun fiksafat eksistensialisme sama-sama menempatkan cara wujud manusia sebagai tema sentral.

51 Harry Hamersma, Op, Cit, hlm.79

52 Ibid. 
dengan dosa. Dia bebas untuk menentukan nasibnya dan menjadi manusia super. Manusia super, menurut Nietzsche, adalah tujuan manusia, lawanya adalah manusia budha yang tidak mewakili ambisi. Kebajikan yang utama adalah kekuatan, yang kuatlah yang menang dan segala yang baik harus kuat. Sebaliknya, yang lemah pasti buruk. ${ }^{53}$

Kematian Allah dan kelahiran supermen. Dalam tulisan ilmu ceria, diceritakan tentang "peristiwa yang paling penting jaman" yaitu kematian Allah. Allah (penemuan dari manusia sendiri) di bunuh oleh manusia. Semakin manusia kurang percaya akan Allah, makin terbuka jalan untuk energinya. Konsep "Allah", kata Nietzsche, merupakan musuh terpenting untuk konsep "eksestensi". Ide "Allah" berperang dengan "hidup". Lalu kematian ide "Allah" membuka jalan untuk hidup manusia. Kalau meninggal, manusia sendiri menjadi semacam keilahian, Uebermensch superman. ${ }^{54}$

\section{J.P Sartre}

a. Riwayat hidup

Jean-Paul Sartre lahir di Paris, tahun 1905. Ia terkenal melalui novel-novelnya, drama-drama tulisanya dan cerita-cerinta pendeknya. Karyanya dalam filsafat yang pokok adalah Being and Nothingness, suatu karya besar yang membicarakan tentang alam, bentuk-bentu eksistensinya atau "being". Setelah perang dunia II, ia menggabungkan diri dengan tentara perancis dan pergerakan pembebasan. Ia adalah penyokong gerakan-gerakan yang berhaluan kiri dan pembela kebebasan manusia. Ia mengatakaan "manusia tidak mempuyai sandaran keagamaan atau tidak dapat mengandalkan pada kekuatan diluar dirinya, manusia harus mengendalikan kekuatan dirinya sendiri. ${ }^{55}$

Menurut Harry Hamersma Sarte merasa banyak bersimpati untuk ajaran Marx tetapi ia terus menerus mengkritik tafsiran ajaran Marx di negara-negara komunis. Pada akhir hidupnya ia makin aktif dalam revolusi-revolusi mahasiswa dan dalam "Russell-tribunal" melawan politik Amerika di Viatnam. Sartre tidak pernah menikah secara resmi. Ia meninggal pada tahun $1980 .{ }^{56}$ b. pengaruh Jean-Paul Sartre

Filsafat Sartre sangat populer dan berpengaruh antara tahun 1945 dan 1970. Sartre mengukapkan perasaan hidup angkatan yang setelah dua perang dunia agak acuh tak acuh terhadap nilai-nilai tradisional. Bahwa Sartre begitu berpengaruh juga disebabkan oleh bentuk tulisan-tulisannya. Sartre mendapet hadia nobel, tqhun 1963 (yang ditolaknya). Pengaruh Sartre berkurang pada akhir hidupnya. ${ }^{57}$

c. Pikiran-pikiran pokok

Sebagaimana tokoh-tokoh Ateisme yang lain demikian juga Sartre tidak mempercayai eksistensi Tuhan. Menurut Pengakuannya dia kehilangan keyakinan ketika umur 11 tahun.

53 Fuad Hasan, bekrkenalan dengan Eksistensialisme, Jakarta, Pustaka Jaya, Cet.4, 1989, hlm. 48

54 Harry Hamersma, $\mathrm{Op}$, Cit, hlm. 81

55 Titus dkk, Op, Cit, hlm. 395.

56 Harry Hamersma, Op, Cit, hlm 107.

57 Ibid. 
Tuhan, kata Sartre, bukan merupakan hal yang jelas bagi dia, sehingga Sartre menganggap sama sekali tidak ada manfaatnya untuk menelitih dan membuktikan kesalahan argumen tradisional dan medern tentang eksistensi Tuhan. Sartre berpendapat bahwa Tuhan atau Allah hanya merupakan proyeksi jiwa manusia.$^{58}$ Menurut Sartre, Hipotesis tentang Tuhan atau Allah tidak diperlukan untuk mewujudkan dan memahami eksistensi manusia. Baik Tuhan ada atau tidak ada tidak mengubah kondisi nyata manusia, demikian pendapat Sartre. Sebab, seandainya Tuhan ada, manusia ada sebagai pelindung par excellemce, paling sempurna dari tatanan nilainilai moral dan rasional yang mapan. Tuhan harus ditolak atas nama kebebasan. ${ }^{59}$

Menurut Sartre kebebasan manusia adalah mutlak dan sekaligus merupakan hukuman, sebagaimana pohon dihukum menjadi pohon, manusia dihukum menjadi bebas. Di balik kebebasan itu, manusia di tuntut bertanggung jawab terhadap dirinya sendiri. Artinya, manusia menemukan kebebasan, tetapi justru kebebasan tersebut dirasakannya sebagai beban yang berat. Tidak ada yang dapat meringankan beban tersebut, termasuk Tuhan. Menurut Sartre, Tuhan tidak dapat dimintai bertanggung jawab dan tidak bisa dijadikan untuk menggantungkan tanggung jawab. oleh karena itu, dan kebebasan yang dimiliki manusia maka manusia bertanggung jawab. 60

Bagaimana kebebasan berperan dalam tingkah laku manusia? Dalam menjawab pertayaan ini Sartre berpendapat bahwa kebebasan manusia bukan merupakan suatu kemapuan juga buka merupakan salah satu sifat kehendak. Menurut Sartre kebebasan adalah absolut dan sekaligus hukuman bagi manusia, kebebasan tidak dapat bertumbuh pada sesuatu yang lain, selain kebebasan itu sendiri.

Konsepsi tentang kebebasan menjadi alasan menjadi Ateismeme sartre. Menurut Sartre seandainya Tuhan ada tidak mungkin saya bebas. Tuhan Maha Tahu dan sudah mengetahui segala-galanya sebelum saya melakukan dan Tuhan pulalah yang akan menentukan hukuman moral. ${ }^{61}$ Humanisme dan Eksistensialisme mendasari konsep Ateismeme pada kebebasan manusia. Manusia sebagai mahkluk yang tertinggi dibandingkan dengan mahkluk lain yang memiliki cara berada yang sama sekali berbeda. Perbedaan itu terletak pada kebebasan bertindak. Menurut Humanisme dan Eksistensialisme sama-sama meletakan manusia sebagai fokus sentra dan tertinggi. Menurut mereka bentuk ketinggian lain yang terbentuk supernatural harus dinigasikan karena mengambat kebebasan manusia.

Menurut aliran Eksistensialisme, jati diri manusia, selama ini telah digrokoti oleh agama dan institusi-institusi yang mapan dan bersifat masif. Untuk mengembalikan jati diri yang asli, manusia harus membebaskan diri dari seluruh keterikatan tersebut. Oleh karena itu aliran Eksistensialisme tidak saja anti agama tetapi anti nilai-nilai yang mapan. ${ }^{62}$

Munculnya Eksistensialisme tidak dapat dipisahkan dari kondisi Eropa pada kala itu yaitu

58 Ignace Lepp, Ateismeme Dewasa Ini, Yogyakarta, Solhudin Press, 1985, hlm. 138

59 Amsal Bakhtiar, Op, Cit, hlm. 152

60 Fuad Hasan, $O p$, Cit, hlm. 144

61 Amsal Bakhtiar, Op, Cit, hlm. 154

$62 \mathrm{Ibid}$, hlm. 155 
mulai abad pencerahan dan lahirnya proses massifikasi oleh berbagai institusi, baik agama maupun Negara.

Bertitik tolak dari paparan di atas maka paham Eksistensialisme tidak perlu di khawatirkan oleh agamawan di kawasan lain karena kondisinya tidak sama. Yang perlu dicermati adalah manakala suatu pemikiran atau nilai terlalu diabsolutkan, maka reaksi akan mucul dari berbagai pihak. Tuhan yang di bunuh Nietzsche adalah Tuhan 'akibat' bukan Tuhan 'sebab' Tuhan sebagai pencipta alam tidak disinggung oleh Nietzsche karena memang tidak mendatangkan hasil kehidupan. Yang di tentang Nietzsche adalah Tuhan orang Eropa yang meyengsarakan rakyat. Seandainya ada Tuhan 'yang sesuai dengan ide Nietzsche, tentu Nietzsche mengakuinya. Dan untuk itu Nietzsche memang menciptakan Tuhan sendiri yang bernama Zarathustra, yaitu dirinya sendiri.

\section{Penutup}

Bertitik tolak dari beberapa paparan dan kutipan di atas, maka dapat di simpulkan hal-hal sebagai berikut:

1. Bahwa ataiesme adalah paham dalam filsafat yang menolak terhadap pondasi agama dalam moralitas dan penolakan terhadap eksistensi Tuhan dan hari kebangkitan, mukjizat, atau pewahyuan dan naskah kitab suci. Oleh karena itu Ateismeme ialah musuh kemanusiaan, musuh agama dan kepercayaan terhadap Tuhan.

2. Ateismeme didunia Barat didukung oleh beberapa aliran filsafat, seperti : aliran filsafat Empirisme dengan tokohnya David Hume, aliran Materialisme dengan tokohnya Ludwig Andreas Feuerbach dan Karl Marx, aliran filsafat Positivisme dengan tokohnya Auguste Comte, dan filsafat Humanisme dan Eksistensialisme dengan tokohnya Nietzsche dan J.P Sartre. Isme-isme tersebut di samping tidak mengakui adanya eksistensi Tuhan juga mengadakan serangan-serangan dengan gencar terhadap Tuhan dan Agama. Bagi Isme-isme tersebut sesuatu dipandang sebagai benda yang bisa di lihat secara indra saja. Oleh karena itu ia menolak sesuatu bernuansa metafisis.

3. Bahwa orang yang mempuyai paham Ateisme mempuyai beberapa alasan : a). ia menganggap dunia empiris ini merupakan keseluruan realita. Adanya alam tidak membutuhkan adanya bantuan dari luar semua kejadian di alam berada dalam suatu siklus yang terus berjalan, sehingga tidak membutuhkan adanya kehadiran pihak lain untuk memahami alam, naturalisme bertentangan dengan supranaturalisme. b). Jika Tuhan betul-betul Maha Kasih, tentunya akan menghapus kejahatan. Apabila ia Maha Kuasa pasti akan menghapus kejahatan ini. Kenyataanya kejahatan ini tetap ada, oleh karenanya Tuhan tidak dapat bersifat Maha Kuasa dan Maha Kasih. c). Manakala Tuhan ada, maka manusia secara otomatis tidak mempuyai kebebasan. Padahal kenyataanya manusia bebas, jadi Tuhan tidak ada. d). Kepercayaan kepada Tuhan hanya merupakan hasil dari pikiran harapan dan kebisaan masyarakat. Oleh karena itu, pemikiran Isme-isme di atas didasarkan atas hawa nafsu kebutuhan dan keputus-asaan yang ambisius. 
112 | M. Baharudin

\section{Bibliografi}

Achmadi, Asmoro, Filsafat Umum, PT Raja Grafindo Persada, Jakarta, 2009.

Al Bahiy, Muhammad, Pemikiran Islam Modern, Judul Asli "Al fikrul Islam Al Hadist Wa Shiratuhu bil Istimaril Garbiyyi” Jakarta, Pustaka Panjimas, 1986,

Bakhtiar, Amsal, Filsafat Agama: Wisata Pemikiran dan Kepercayaan Manusia, Jakarta, Raja rafindo Persada, 2009

Brouwer, M.A.W, Sejarah Filsafat Barat Modern dan Sejaman, Alumni, Bandung, 1980

Bachtiar, Harsja W. (ed), percakapan dengan Sidney Hook tentan 4 Masalah Filsafat, Jakarta, Jambatan, 1980

Bertens, K, Ringkasan Sejarah Filsafat, Yogyakarta, Kanesius, 1981.

Hardiman, Budi, Filsafat Modern: dari Machiveli sampai Nietzsche, Jakarta, Gramedia, Pustaka Utama, 2004.

Hume, Davit, An Enguiry concerning Human Uanderstanding, (Chicago: Chicago University, 1952.

Hamka, Filsafat Ketuhanan, C.V Karunia, Surabaya, 1985.

Hasan, Fuad, bekrkenalan dengan Eksistensialisme, Jakarta, Pustaka Jaya, Cet.4, 1989

Hamersma, Harry, Theologi Metafisik, Yogyakarta Seminari, 1978

Hossein Nasr, Seyyed, Menjelajah Dunia Modern: Bimbingan Kaum Muda Muslimin, Mizan, Bandung, 1994

Lepp, Ignace, Ateismeme Dewasa Ini, Yogyakarta, Solhudin Press, 1985

Kattsoff O. Louis, Pengantar Filsafat. Di Terjemahkan dari Buku Elements Of Philosophy. Ahli Bahasa Soejono Soemargono, Yogyakarta, Tiara Wacana, 1987.

Kuswanjono, Arqom, Ketuhanan Dalam Telaah Filsafat Perennial: Refleksi Pluralisme Agama di Indonesia, Yogyakarta, Badan Penerbit Filsafat UGM, 2006.

Leahy, Louis, Filsafat Ketuhanan Kontemporer, Kanisius, Yogyakarta, 1993.

Nasution Harun, Filsafat Agama, Bulan bintang, Jakarta, 1973.

N.A Rasyid Dt Mangkudun, Ketuhanan Yang Maha Esa Menurut Konsep Tauhid, ( Jakarta, karya Indah) 1984.

Rasjidi, Filsafat Agama, Bulan Bintang, Jakarta, 1970.

Roth, K. John, Persoalan-persoalan filsafat Agama: Kajian Pemikiran 9 Tokoh dalam Sejarah Filsafat dan Teologi, Pustaka Pelajar, Yogyakarta, 1974.

Saifuddin Anshari Endang, Ilmu Flsafat \& Agama, Surabaya, Bina Ilmu, 1979 
Titus dkk, Persoalan-persoalan filsafat, Jakarta, Bulan Bintang, 1974

Wiliam L. Reese dan Charles Hartshorne, Philophers Speak OfGod, Chicago: The University Ff Chicago Press, 1953

Yáqub, Hamzah, Filsafat Agama: Titik Temu Akal dengan Wahyu, Pedoman Ilmu Jaya, Jakarta, 1992. 